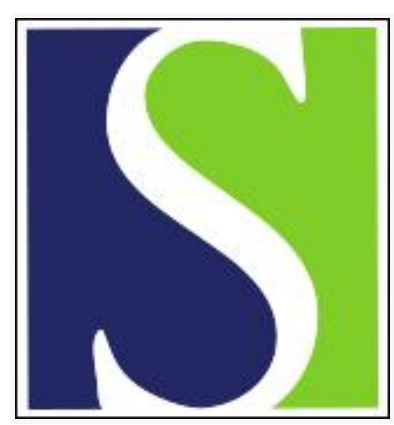

Scand J Work Environ Health 2010;36(4):339-348

https://doi.org/10.5271/sjweh.2892

Published online: 12 Jan 2010, Issue date: 01 Jun 2010

Trends and priorities in occupational health research and knowledge transfer in Italy

by Rondinone BM, Boccuni F, lavicoli S

Affiliation: Bruna Maria Rondinone, ISPESL, Department of Occupational Medicine, 00040 - Monteporzio Catone (RM), Italy. bruna.rondinone@ispesl.it

Key terms: consensus; Delphi technique; health research; Italy; knowledge transfer; occupational health research; occupational safety and health; OSH; priority; research priority; stakeholder; trend

This article in PubMed: www.ncbi.nlm.nih.gov/pubmed/20066387 


\title{
Trends and priorities in occupational health research and knowledge transfer in Italy
}

\author{
by Bruna Maria Rondinone, MS, ${ }^{1}$ Fabio Boccuni, MEng, ${ }^{1}$ Sergio lavicoli, MD, PhD ${ }^{1}$
}

Rondinone BM, Boccuni F, lavicoli S. Trends and priorities in occupational health research and knowledge transfer in Italy. Scand J Work Environ Health. 2010;36(4):339-348.

\begin{abstract}
Objectives In 2000-2001, the Italian National Institute for Occupational Safety and Prevention (ISPESL) carried out a survey to identify the research priorities in the field of occupational safety and health (OSH). The present study, carried out in 2007-2008, was a follow-up designed to (i) review the themes identified earlier, (ii) detect emerging issues linked to new risks and forms of work, and (iii) look for any shifts in focus. The survey was extended to cover not only research but also the concept of knowledge transfer.
\end{abstract}

Methods In the first round, ISPESL distributed questionnaires to the heads of both university occupational medicine departments and prevention departments in local national health units (known as ASL in Italy) asking respondents to identify OSH priority themes. In the latest survey, covering both research and the need for knowledge transfer, the same experts were asked to rank the importance of the earlier-identified topics and list any emerging issues in the OSH field.

Results The two most important themes identified were "work accidents" and "occupational carcinogenesis". In the overall sample and among ASL experts, they received the $1^{\text {st }}$ and $2^{\text {nd }}$ highest mean scores. The university respondents also prioritized them but in reverse order. Some of the new priority topics included: risks associated with nanotechnologies; assessment of psychosocial and organizational risks; migration and work; and costbenefit analysis of prevention.

Conclusion In light of the findings, efforts are urgently needed to identify research and knowledge transfer priorities related to workers' health and safety on an international scale using a standardized method in order to obtain comparable results, avoid wasteful duplication of resources, and reduce occupational accidents and illness.

Key terms consensus; Delphi technique; occupational safety and health; OSH; research priority; stakeholder.

The Global Forum for Health Research, an independent, international organization committed to demonstrating the essential role of research and innovation for health and health equity for the benefit of poor and marginalized populations, has promoted the identification of occupational safety and health (OSH) in the broader context of health research priority-setting. The focus on OSH has attracted attention due to limitations in resources and financing at local, national, and international government levels for research in this field. The failure to establish priorities for public health research has led to a situation where only about $10 \%$ of health research funds from public and private sources are devoted to $90 \%$ of the world's health problems (1).

In the OSH field, it is especially difficult to identify research priorities due to the large numbers of "factors and actors" involved, and the multidisciplinary nature of the many OSH topics, which can range from toxicology, molecular biology, epidemiology, and hygiene to occupational medicine. However, a subjective approach to the process of identifying priorities, inevitably reflecting the personal experience of all the individuals involved, should in fact guarantee objective results by using valid, standardized procedures and calling into play the expertise of all those working on health and safety at work, whatever the focus.

Various studies have been done in different parts of the world to identify OSH priority themes (2-12) and critical comparative analyses have focused on the approaches used to consult experts, the methods of investigation employed, the results found, and their impact on social, economic, political, and scientific decisions $(13,14)$.

1 Italian National Institute for Occupational Safety and Prevention (ISPESL), Department of Occupational Medicine, Monteporzio Catone (RM), Italy.

Correspondence to: Bruna Maria Rondinone, ISPESL, Department of Occupational Medicine, Via Fontana Candida 1, 00040 - Monteporzio Catone (RM), Italy. [E-mail: bruna.rondinone@ispesl.it] 
Many of these studies have used the Delphi technique - pure or modified - because it offers advantages over other methods, especially when the aim is to identify areas of consensus or divergence. The method involves presenting one or more topics to a group of experts in a certain sector, taking them through an iterative process, and asking for their personal assessments which, as they can shift at each successive round, lead to a group consensus with all replies remaining anonymous.

The most sensitive part of the Delphi method is the formation of the panel of experts. Since it is not guaranteed by the sampling theory to ensure reliable and unbiased findings, the panel must be designed to ensure a high level of representativeness. Establishing priorities in $\mathrm{OSH}$ is an ongoing process because topics designated as a priority must be constantly updated and systematically reviewed to ensure they keep abreast of change in the world of work as a whole, employment, and all aspects of health and safety in jobs where new risk factors come to light, making it necessary to revise exposure models used for existing risks.

In Italy, the National Institute for Occupational Safety and Prevention (ISPESL), a government agency that does research, initiates regulations, and provides consultancy services, training, and information on OSH, carried out a survey in 2000-2001, drawing up a list of OSH research themes that merited priority (7-9). Six years later, ISPESL redid this exercise with a view to reorienting $\mathrm{OSH}$ research priorities from a longterm perspective, taking into consideration not only the research itself but also the concept of knowledge transfer.

The gap between theory and practice leads not only to the under-use of effective OSH interventions or treatments but also to their incorrect use and the potential promotion of unhelpful or unproven remedies. The realization that failure to apply research findings to healthcare can have a negative impact on patient care has led to an increased emphasis on finding and using appropriate ways of transferring research into practice. This process is commonly referred to as "knowledge transfer" and, in recent years, has become a significant focus for policy-makers, researchers, and activities that link research-generated evidence to policy.

Knowledge transfer has been defined as a systematic approach to capture, collect, and share tacit knowledge in order for it to become explicit (articulated, codified and stored). This process allows individuals and/or organizations to access and utilize essential information, previously known intrinsically to only one individual or a small group of people. Knowledge transfer is about transferring good ideas, research results, and skills to universities, other research organizations, businesses, and the wider community to enable the development of innovative new products and services $(15,16)$.
The aims of this 2007-2008 study, therefore, were to review the priority topics identified in 2000-2001, identify any shifts in focus between the two periods, and detect emerging problems linked to new risks and new forms of work and work organization. Unlike, the previous study, the present survey addressed priority themes from both a research and knowledge transfer perspective.

\section{Methods}

As the first step in this priority-setting program in 20002001, using the Delphi technique, ISPESL distributed an ad hoc questionnaire in two cycles to the two main stakeholders involved in OSH on a daily basis in Italy: (i) university occupational medicine and health departments and (ii) heads of prevention departments in local national health units (known as ASL in Italy). Situated throughout the country, ASL are autonomous bodies of the Italian national health system that organize and plan the healthcare system for specific areas so as to provide services in the community closer to where people live. Each ASL includes a department of prevention responsible for occupational medicine and environmental surveillance services.

On the basis of the replies, ISPESL drafted a list of $27 \mathrm{OSH}$ research priority topics. The questionnaire and results of the earlier survey have been analyzed and described in detail elsewhere (7-9).

In 2007-2008, the long-term priorities were identified again by sending a questionnaire to the same ASL and university departments. Table 1 compares the numbers of replies received during the two stages. The questionnaire used in the second phase was selfadministered and comprised three sections. The first required information about the recipient institution and the name of a contact person in the organization, where appropriate. The second presented 27 topics (the earlier identified priorities), grouped in 5 "macro-sectors". Respondents were asked to rank the topics by importance, with regard to research and knowledge transfer, using the following categories: (i) not very important; (ii) fairly important; (iii) moderately important; (iv) very important; (v) extremely important. The final section contained open questions asking respondents to list briefly $\leq 5$ other topics they considered important in terms of research and efforts for knowledge transfer, but only when the list of the 27 aforementioned topics was considered incomplete. They were then asked to rank their additions in order of importance, using the categories set out above.

The questionnaire was accompanied by a letter introducing and describing the study and requesting 
Table 1. Numbers of respondents to the questionnaires in the two stages.

\begin{tabular}{|c|c|c|c|c|c|c|c|c|c|}
\hline & \multicolumn{3}{|c|}{$\begin{array}{l}\text { Local health units } \\
\text { (known as ASL in Italy) }\end{array}$} & \multicolumn{3}{|c|}{$\begin{array}{l}\text { University occupational } \\
\text { medicine departments }\end{array}$} & \multicolumn{3}{|c|}{ Total sample } \\
\hline & $\begin{array}{l}\text { Sent } \\
(N)\end{array}$ & $\begin{array}{l}\text { Received } \\
\text { (N) }\end{array}$ & $\begin{array}{c}\text { Respondents } \\
(\%)\end{array}$ & $\begin{array}{c}\text { Sent } \\
(N)\end{array}$ & $\begin{array}{l}\text { Received } \\
\text { (N) }\end{array}$ & $\begin{array}{l}\text { Respondents } \\
(\%)\end{array}$ & $\begin{array}{c}\text { Sent } \\
(N)\end{array}$ & $\begin{array}{l}\text { Received } \\
\text { (N) }\end{array}$ & $\begin{array}{c}\text { Respondents } \\
(\%)\end{array}$ \\
\hline \multicolumn{10}{|l|}{$1^{\text {st }}$ stage $2000-2001$} \\
\hline $\begin{array}{l}\text { Cycle I } \\
\text { Cycle II }\end{array}$ & 179 & $\begin{array}{r}75 \\
102\end{array}$ & $\begin{array}{l}41.9 \\
57.0\end{array}$ & 131 & $\begin{array}{l}100 \\
101\end{array}$ & $\begin{array}{l}76.3 \\
77.1\end{array}$ & 310 & $\begin{array}{l}175 \\
203\end{array}$ & $\begin{array}{l}56.4 \\
65.5\end{array}$ \\
\hline $2^{\text {nd }}$ stage $2007-2008$ & 180 & 122 & 67.8 & 87 & 60 & 69.0 & 267 & 182 & 68.2 \\
\hline
\end{tabular}

informed consent to use the data as required by the Italian law on privacy (No 196/2003). Respondents could reply by mail, fax, or online via the ISPESL site, using the log-in procedure with a password provided by the Institute. Half of the respondents compiled the questionnaire online, more than a third sent their replies by fax $(37.3 \%)$, and the rest by mail $(12.7 \%)$.

This second survey was based on the findings of the first stage (ie, the 2000-2001 survey), providing respondents with a chance to rank the importance of topics identified earlier, and enabling ISPESL to see whether there had been any changes in focus. The survey also presented an opportunity to list any problems emerging in the $\mathrm{OSH}$ field related to research and knowledge transfer.

\section{Statistical analysis}

We conducted our statistical analysis using the Statistical Package for the Social Sciences, version 15.0 (SPSS Inc, Chicago, IL, USA). Mean scores were calculated for (i) each of the 27 topics, (ii) the sample as a whole, and for greater detail, (iii) the university and ASL respondents separately. We calculated the mean scores for both the field of research - already presented in the first stage - and the transfer of the results and knowledge, which only appeared in the second stage.

To check whether the mean scores for research differed significantly between the two stages, we applied Student's one sample t-test on the sample as a whole and for the university and ASL respondents separately. The mean scores were then compared for each of the 27 topics, the two groups of experts, and both research and knowledge transfer using the Mann-Whitney non-parametric $U$ test. Considering the judgments on research and knowledge transfer priorities expressed in the questionnaires as paired data, we used Wilcoxon's non-parametric test to establish the difference between mean scores for these two categories.

We then proceeded to identify the new research and knowledge transfer priorities. The responses were grouped in homogeneous categories; we isolated topics that did not overlap with earlier ones and only those issues mentioned in at least nine responses. This served as the basis for a list of new priorities using a mean score corrected to take account of the numbers of experts who had mentioned a subject. Values with $\mathrm{P}<0.05$ were considered significant.

\section{Results}

The sample included 182 experts in different areas related to workers' health and safety. A majority of respondents (67\%) were from ASL prevention departments, the rest (33\%) were from universities, comprising mainly ordinary and associate professors of occupational medicine.

Table 2 shows the mean scores and ranking of the 27 priorities and the significance of any differences for the total sample and the university and ASL experts separately, for the latter and first stages of the study (7-9). The topic that attracted the highest mean score in the overall sample was "work accidents" (4.25) followed by "occupational carcinogenesis" (4.24) and "quality in occupational medicine" (3.92). The two groups differed in their prioritization of topics: the universities put "occupational carcinogenesis" (4.07) in $1^{\text {st }}$ place, followed by "work accidents" (4.00), and $3^{\text {rd }}$ came "biological monitoring" and "occupational exposure to urban chemical pollutants" [equal score (3.68)]. The ASL experts put the same two topics as in the overall sample $1^{\text {st }}$ and $2^{\text {nd }}$, but in $3^{\text {rd }}$ place put "organisation, strategies and optimization of prevention and safety services at the workplace" (4.09). Using Student's one sample t-test, we found some significant differences between the means for the two samples. In the overall sample and in the two groups separately, the topics that showed a definite shift in tendency compared to the first survey were "work accidents", "biological agents" and "electromagnetic fields". For the first topic, the mean scores for all groups were significantly higher than in 2000-2001, so "work accidents" moved up in the research priorities ranking. For the other two topics, the shift was downward, with significantly lower mean scores than previously. 
Table 2. Mean scores and (rank) for the 27 research priority topics, comparision of 2007-2008 with 2000-2001. Each topic falls under a macro-sectors defined as : A) diseases and work accidents; B) risk assessment; C) work environment, workforce, and working sectors; D) mechanism of action and development of indicators; E) research methods, approaches and strategies. (ASL=local national health unit, NS=not significant)

\begin{tabular}{|c|c|c|c|c|c|c|c|c|c|c|c|c|c|c|c|c|}
\hline \multicolumn{2}{|c|}{ Macro-sector topics } & \multicolumn{4}{|c|}{ University } & \multirow{3}{*}{$\begin{array}{c}\text { P- } \\
\text { - value a }\end{array}$} & \multicolumn{4}{|c|}{ ASL } & \multirow{3}{*}{ P- } & \multicolumn{4}{|c|}{ Total } & \multirow{3}{*}{$\begin{array}{l}\text { P- } \\
- \text { value }^{\text {a }} \\
18\end{array}$} \\
\hline & & \multicolumn{2}{|c|}{ 2000-2001 } & \multicolumn{2}{|c|}{$2007-2008$} & & \multicolumn{2}{|c|}{ 2000-2001 } & \multicolumn{2}{|c|}{ 2007-2008 } & & \multicolumn{2}{|c|}{ 2000-2001 } & \multicolumn{2}{|c|}{ 2007-2008 } & \\
\hline & & $\begin{array}{l}\text { Mean } \\
\text { score }\end{array}$ & Rank & $\begin{array}{l}\text { Mean } \\
\text { score }\end{array}$ & Rank & & $\begin{array}{l}\text { Mean } \\
\text { score }\end{array}$ & Rank & $\begin{array}{l}\text { Mean } \\
\text { score }\end{array}$ & Rank & & $\begin{array}{l}\text { Mean } \\
\text { score }\end{array}$ & Rank & $\begin{array}{l}\text { Mean } \\
\text { score }\end{array}$ & Rank & \\
\hline A & Work accidents & 3.50 & 15 & 4.00 & 2 & 0.002 & 3.99 & 6 & 4.37 & 1 & $<0.001$ & 3.75 & 9 & 4.25 & $1<<x$ & $<0.001$ \\
\hline D & Occupational carcinogenesis & 4.31 & 1 & 4.07 & 1 & NS & 4.33 & 3 & 4.32 & 2 & NS & 4.32 & 1 & 4.24 & 2 & NS \\
\hline $\mathrm{E}$ & Quality in occupational medicine & 3.88 & 4 & 3.66 & 5 & NS & 4.41 & 1 & 4.05 & 4 & $<0.001$ & 4.15 & 2 & 3.92 & 3 & 0.003 \\
\hline $\mathrm{E}$ & $\begin{array}{l}\text { Organization, strategies and } \\
\text { optimization of prevention and safety } \\
\text { services at the workplace }\end{array}$ & 3.34 & 19 & 3.41 & 17 & NS & 4.38 & 2 & 4.09 & 3 & 0.006 & 3.87 & 5 & 3.87 & 4 & NS \\
\hline A & $\begin{array}{l}\text { Musculoskeletal and repetitive } \\
\text { trauma disorders }\end{array}$ & 3.50 & 15 & 3.66 & 5 & NS & 3.78 & 8 & 3.93 & 5 & NS & 3.64 & 12 & 3.84 & 5 & 0.007 \\
\hline D & $\begin{array}{l}\text { Exposure to low doses and } \\
\text { multiple exposure }\end{array}$ & 3.99 & 2 & 3.53 & 12 & NS & 4.00 & 5 & 3.90 & 7 & NS & 4.00 & 3 & 3.78 & 6 & NS \\
\hline E & $\begin{array}{l}\text { Worker information, education } \\
\text { and participation }\end{array}$ & 3.73 & 7 & 3.51 & 13 & 0.006 & 4.04 & 4 & 3.92 & 6 & NS & 3.89 & 4 & 3.78 & 6 & 0.008 \\
\hline A & New work-related diseases & 3.79 & 6 & 3.61 & 7 & NS & 3.75 & 9 & 3.79 & 9 & NS & 3.77 & 7 & 3.73 & 8 & NS \\
\hline$E$ & Work organization and new types of work & 3.59 & 12 & 3.48 & 15 & NS & 3.73 & 10 & 3.86 & 8 & NS & 3.66 & 11 & 3.73 & 8 & NS \\
\hline$E$ & $\begin{array}{l}\text { Medical surveillance and work ability } \\
\text { criteria }\end{array}$ & 3.67 & 10 & 3.36 & 18 & 0.044 & 3.87 & 7 & 3.77 & 10 & NS & 3.77 & 7 & 3.63 & 10 & NS \\
\hline$E$ & $\begin{array}{l}\text { Biological monitoring: identification } \\
\text { of markers for low-dose exposure }\end{array}$ & 3.94 & 3 & 3.68 & 3 & NS & 3.72 & 11 & 3.58 & 13 & NS & 3.83 & 6 & 3.61 & 11 & 0.007 \\
\hline B & Load handling & 3.19 & 26 & 3.22 & 23 & NS & 3.53 & 13 & 3.70 & 11 & NS & 3.36 & 20 & 3.55 & 12 & 0.016 \\
\hline B & Asbest & 3.60 & 11 & 3.32 & 19 & 0.032 & 3.51 & 15 & 3.59 & 12 & NS & 3.55 & 14 & 3.50 & 13 & NS \\
\hline C & Healthcare and hospital sector & 3.70 & 9 & 3.56 & 9 & NS & 3.52 & 14 & 3.46 & 14 & NS & 3.61 & 13 & 3.49 & 14 & NS \\
\hline C & $\begin{array}{l}\text { Special populations at risk (elderly, } \\
\text { minors, disabled people) }\end{array}$ & 3.24 & 24 & 3.42 & 16 & NS & 3.42 & 18 & 3.46 & 14 & NS & 3.33 & 21 & 3.45 & 15 & NS \\
\hline$E$ & $\begin{array}{l}\text { Methods of assessing and measuring } \\
\text { occupational stress }\end{array}$ & 3.29 & 23 & 3.59 & 8 & 0.026 & 3.28 & 22 & 3.31 & 17 & NS & 3.29 & 25 & 3.41 & 16 & NS \\
\hline D & $\begin{array}{l}\text { Mechanism of action of occupational } \\
\text { stress and occurrence of disease }\end{array}$ & 3.33 & 21 & 3.55 & 10 & NS & 3.30 & 21 & 3.26 & 18 & NS & 3.32 & 22 & 3.36 & 17 & NS \\
\hline B & $\begin{array}{l}\text { Occupational exposure to urban } \\
\text { chemical pollutants }\end{array}$ & 3.53 & 14 & 3.68 & 3 & NS & 3.12 & 25 & 3.19 & 19 & NS & 3.32 & 22 & 3.35 & 18 & NS \\
\hline C & Agriculture & 3.30 & 22 & 3.15 & 24 & NS & 3.45 & 17 & 3.42 & 16 & NS & 3.38 & 19 & 3.33 & 19 & NS \\
\hline D & $\begin{array}{l}\text { Individual susceptibility and development } \\
\text { of susceptibility indicators }\end{array}$ & 3.84 & 5 & 3.55 & 10 & NS & 3.23 & 24 & 3.07 & 21 & NS & 3.53 & 15 & 3.23 & 20 & 0.001 \\
\hline A & Reproductive and pregnancy disorders & 3.22 & 25 & 3.51 & 13 & 0.014 & 3.39 & 20 & 2.99 & 24 & $<0.001$ & 3.31 & 24 & 3.16 & 21 & NS \\
\hline A & Occupational allergies & 3.50 & 15 & 3.32 & 19 & NS & 3.42 & 18 & 3.07 & 21 & $<0.001$ & 3.46 & 16 & 3.15 & $22<$ & $<0.001$ \\
\hline A & $\begin{array}{l}\text { Occupational asthma and respiratory } \\
\text { diseases }\end{array}$ & 3.57 & 13 & 3.30 & 21 & NS & 3.28 & 22 & 3.06 & 23 & 0.010 & 3.43 & 18 & 3.14 & 23 & $<0.001$ \\
\hline B & Biological agents & 3.41 & 18 & 3.03 & 25 & 0.010 & 3.46 & 16 & 3.12 & 20 & $<0.001$ & 3.44 & 17 & 3.09 & $24<$ & $<0.001$ \\
\hline C & Air quality and indoor environments & 3.34 & 19 & 3.24 & 22 & NS & 2.94 & 26 & 2.94 & 26 & NS & 3.14 & 26 & 3.04 & 25 & NS \\
\hline B & Electromagnetic fields & 3.71 & 8 & 2.92 & $26<$ & $<0.001$ & 3.68 & 12 & 2.95 & 25 & $<0.001$ & 3.69 & 10 & 2.94 & $26<$ & $<0.001$ \\
\hline D & $\begin{array}{l}\text { Mechanism of skin absorption of } \\
\text { xenobiotics }\end{array}$ & 3.04 & 27 & 2.83 & 27 & NS & 2.81 & 27 & 2.68 & 27 & NS & 2.93 & 27 & 2.73 & 27 & 0.010 \\
\hline
\end{tabular}

a Student's one sample t-test

Analysis of the significant findings in the ASL replies indicated a reduction in demand for research on "quality in occupational medicine" and "organization of prevention and safety services", both of which fall under the broader category of research methods and approaches. The mean scores for "occupational allergies", "occupational asthma", and "reproductive disorders" were also significantly lower than in the first survey.

The universities, in contrast, assigned significantly greater importance to "reproductive disorders" and "methods of assessing and measuring occupational stress", the latter of which rose from $23^{\text {rd }}$ position in 2000-2001 to $8^{\text {th }}$ place in 2007-2008. University departments reported less interest in methodological aspects, such as "worker information, education and participation" and "medical surveillance".

Of the all the topics identified, only some reached $\mathrm{P}<0.05$ in the overall sample, and were at the limit of significance in $\geq 1$ of the two subgroups: these included "musculoskeletal disorders" and "load handling", 
which had higher mean scores than in the earlier survey, and "biological monitoring" and "individual susceptibility", for which there was less demand for research than in 2000.

Table 3 sets out the mean scores for research and knowledge transfer priorities among the total sample and university and ASL groups separately. There are important differences on the topics of "work accidents", "occupational carcinogenesis", "quality in occupational medicine", "organization of prevention and safety services", "worker information, education, and participation", "medical surveillance", and "load handling". For these themes, the ASL showed significantly more interest in research than the universities. In contrast, the universities assigned significantly higher mean scores to the need for more research on "occupational exposure to urban chemical pollutants", "individual susceptibility" and "reproductive disorders".

As regards knowledge transfer, the overall sample and the two subgroups all assigned absolute priority to "work accidents", followed by "occupational carcinogenesis", which also hold the top two positions in the list of research priorities. Using the Mann Whitney U test to analyze the differences between the university and ASL mean scores, we found that the ASL experts felt there was a significantly greater need for knowledge transfer rather than research for many topics. The topics ranged from "occupational carcinogenesis" to "exposure to low doses and multiple exposure", "organisation of prevention and safety services", and "quality in occupational medicine". However, for others, such as "occupational exposure to urban chemical pollutants", "occupational asthma", and "occupational allergies", the university scores were significantly higher than those of the ASL.

For most topics, the experts' opinions did not differ significantly on the dual need for research and knowledge transfer, but a few did attract higher scores for one or the other. Wilcoxon's non-parametric test indicated that the mean scores for "worker information, education and participation" were significantly higher

Table 3. Mean scores and (rank) for the 27 topics; comparison of university and ASL mean scores and between research and knowledge transfer in the total sample and in the two groups separately. Topics fall under macro-sectors defined as: A) diseases and work accidents; B) risk assessment; C) work environment, workforce, and working sectors; D) mechanism of action and development of indicators; E) research methods, approaches and strategies. (ASL=local national health unit, NS=not significant)

\begin{tabular}{|c|c|c|c|c|c|c|c|}
\hline \multicolumn{2}{|c|}{ Macro-sector topics } & \multirow[t]{2}{*}{ Priorities } & \multicolumn{2}{|c|}{ University } & \multirow{2}{*}{$\begin{array}{l}\text { ASL } \\
\begin{array}{l}\text { Mean Rank } \\
\text { score }\end{array}\end{array}$} & \multirow{2}{*}{\begin{tabular}{l}
\multicolumn{1}{c}{ Total } \\
$\begin{array}{l}\text { Mean Rank } \\
\text { score }\end{array}$
\end{tabular}} & \multirow{2}{*}{$\begin{array}{c}\text { P- } \\
\text { value }\end{array}$} \\
\hline & & & $\begin{array}{l}\text { Mean } \\
\text { score }\end{array}$ & Tank & & & \\
\hline A & Work accidents & $\begin{array}{l}\text { Research } \\
\text { Knowledge transfer } \\
\text { P-value Wilcoxon test }\end{array}$ & $\begin{array}{r}4.00 \\
4.07 \\
\text { NS }\end{array}$ & $\begin{array}{l}2 \\
1\end{array}$ & $\begin{array}{ll}4.37 & 1 \\
4.40 & 1 \\
\text { NS } & \end{array}$ & \begin{tabular}{ll}
4.25 & 1 \\
4.29 & 1 \\
\multicolumn{2}{c}{ NS }
\end{tabular} & $\begin{array}{r}0.031 \\
\text { NS }\end{array}$ \\
\hline $\mathrm{D}$ & Occupational carcinogenesis & $\begin{array}{l}\text { Research } \\
\text { Knowledge transfer } \\
\text { P-value Wilcoxon test }\end{array}$ & $\begin{array}{r}4.07 \\
4.02 \\
\text { NS }\end{array}$ & $\begin{array}{l}1 \\
2\end{array}$ & \begin{tabular}{lr}
4.32 & 2 \\
4.28 & 2 \\
\multicolumn{2}{|c}{$N{ }^{2}$}
\end{tabular} & \begin{tabular}{ll}
4.24 & 2 \\
4.19 & 2 \\
\multicolumn{2}{c}{$N S^{2}$}
\end{tabular} & $\begin{array}{l}0.045 \\
0.030\end{array}$ \\
\hline$E$ & Worker information, education, and participation & $\begin{array}{l}\text { Research } \\
\text { Knowledge transfer } \\
\text { P-value Wilcoxon test }\end{array}$ & $\begin{array}{r}3.51 \\
3.80 \\
0.0\end{array}$ & $\begin{array}{r}13 \\
3 \\
1\end{array}$ & $\begin{array}{cc}3.92 & 6 \\
4.08 & 5 \\
0.043\end{array}$ & $\begin{array}{cr}3.78 & 6 \\
3.98 & 3 \\
0.002\end{array}$ & $\begin{array}{r}0.016 \\
\text { NS }\end{array}$ \\
\hline A & Musculoskeletal and repetitive trauma disorders & $\begin{array}{l}\text { Research } \\
\text { Knowledge transfer } \\
\text { P-value Wilcoxon test }\end{array}$ & $\begin{array}{r}3.66 \\
3.61 \\
\text { NS }\end{array}$ & $\begin{array}{l}5 \\
6\end{array}$ & $\begin{array}{ll}3.93 & 5 \\
4.09 & 3 \\
\text { NS } & \end{array}$ & \begin{tabular}{c}
3.84 \\
3.93 \\
\multicolumn{2}{c}{4} \\
NS
\end{tabular} & $\begin{array}{r}\text { NS } \\
0.015\end{array}$ \\
\hline$E$ & $\begin{array}{l}\text { Organization, strategies, and optimization of prevention } \\
\text { and safety services at the workplace }\end{array}$ & $\begin{array}{l}\text { Research } \\
\text { Knowledge transfer } \\
\text { P-value Wilcoxon test }\end{array}$ & $\begin{array}{r}3.41 \\
3.53 \\
\text { NS }\end{array}$ & $\begin{array}{l}17 \\
11\end{array}$ & \begin{tabular}{ll}
4.09 & 3 \\
4.09 & 3 \\
\multicolumn{2}{c}{ NS }
\end{tabular} & \begin{tabular}{ll}
3.87 & 4 \\
3.90 & 5 \\
\multicolumn{2}{c}{ NS }
\end{tabular} & $\begin{array}{l}<0.001 \\
<0.001\end{array}$ \\
\hline$E$ & Quality in occupational medicine & $\begin{array}{l}\text { Research } \\
\text { Knowledge transfer } \\
\text { P-value Wilcoxon test }\end{array}$ & $\begin{array}{r}3.66 \\
3.68 \\
\text { NS }\end{array}$ & $\begin{array}{l}5 \\
4\end{array}$ & $\begin{array}{ll}4.05 & 4 \\
4.00 & 6 \\
\text { NS }\end{array}$ & $\begin{array}{c}3.92 \quad 3 \\
3.896 \\
\text { NS }\end{array}$ & $\begin{array}{l}0.014 \\
0.033\end{array}$ \\
\hline$E$ & Medical surveillance and work ability criteria & $\begin{array}{l}\text { Research } \\
\text { Knowledge transfer } \\
\text { P-value Wilcoxon test }\end{array}$ & $\begin{array}{r}3.36 \\
3.49 \\
\text { NS }\end{array}$ & $\begin{array}{l}18 \\
15\end{array}$ & \begin{tabular}{lr}
3.77 & 10 \\
3.84 & 7 \\
\multicolumn{2}{c}{ NS }
\end{tabular} & $\begin{array}{cr}3.63 & 10 \\
3.72 & 7 \\
\text { NS }\end{array}$ & $\begin{array}{l}0.021 \\
0.050\end{array}$ \\
\hline B & Load handling & $\begin{array}{l}\text { Research } \\
\text { Knowledge transfer } \\
\text { P-value Wilcoxon test }\end{array}$ & $\begin{array}{r}3.22 \\
3.46 \\
N\end{array}$ & $\begin{array}{l}23 \\
17\end{array}$ & 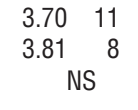 & $\begin{array}{cr}3.55 & 12 \\
3.69 & 8 \\
\text { NS }\end{array}$ & $\begin{array}{l}0.003 \\
0.037\end{array}$ \\
\hline A & New work-related diseases & $\begin{array}{l}\text { Research } \\
\text { Knowledge transfer } \\
\text { P-value Wilcoxon test }\end{array}$ & $\begin{array}{r}3.61 \\
3.56 \\
N\end{array}$ & $\begin{array}{l}7 \\
9\end{array}$ & $\begin{array}{rr}3.79 & 9 \\
3.72 & 10 \\
0.012\end{array}$ & $\begin{array}{rr}3.73 & 8 \\
3.66 & 9 \\
0.007\end{array}$ & $\begin{array}{l}\text { NS } \\
\text { NS }\end{array}$ \\
\hline
\end{tabular}


Table 3. Continued.

\begin{tabular}{|c|c|c|c|c|c|c|c|}
\hline \multicolumn{2}{|c|}{ Macro-sector topics } & \multirow{3}{*}{$\begin{array}{l}\text { Priorities } \\
\text { Research } \\
\text { Knowledge transfer } \\
\text { P-value Wilcoxon test }\end{array}$} & \multirow{2}{*}{\multicolumn{2}{|c|}{$\begin{array}{l}\text { University } \\
\begin{array}{l}\text { Mean Rank } \\
\text { score }\end{array}\end{array}$}} & \multirow{2}{*}{ 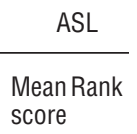 } & \multirow{2}{*}{\begin{tabular}{l}
\multicolumn{1}{c}{ Total } \\
$\begin{array}{l}\text { Mean Rank } \\
\text { score }\end{array}$
\end{tabular}} & \multirow{2}{*}{$\begin{array}{c}\text { P- } \\
\text { value }\end{array}$} \\
\hline & & & & & & & \\
\hline $\mathrm{E}$ & Work organization and new types of work & & $\begin{array}{l}3.48 \\
3.52 \\
\text { NS }\end{array}$ & & $\begin{array}{cr}3.86 & 8 \\
3.71 & 11 \\
0.003\end{array}$ & $\begin{array}{cc}3.73 & 8 \\
3.65 & 10 \\
0.016\end{array}$ & $\begin{array}{l}\text { NS } \\
\text { NS }\end{array}$ \\
\hline D & Exposure to low doses and multiple exposure & $\begin{array}{l}\text { Research } \\
\text { Knowledge transfer } \\
\text { P-value Wilcoxon test }\end{array}$ & $\begin{array}{l}3.53 \\
3.34 \\
\text { NS }\end{array}$ & $\begin{array}{l}12 \\
22\end{array}$ & $\begin{array}{ll}3.90 & 7 \\
3.79 & 9 \\
0.050 & \end{array}$ & $\begin{array}{rr}3.78 & 6 \\
3.64 & 11 \\
0.007\end{array}$ & $\begin{array}{r}\text { NS } \\
0.020\end{array}$ \\
\hline C & Healthcare and hospital sector & $\begin{array}{l}\text { Research } \\
\text { Knowledge transfer } \\
\text { P-value Wilcoxon test }\end{array}$ & $\begin{array}{l}3.56 \\
3.58 \\
\text { NS }\end{array}$ & $\begin{array}{l}9 \\
7\end{array}$ & $\begin{array}{l}3.46 \quad 14 \\
3.53 \quad 13 \\
\text { NS }\end{array}$ & $\begin{array}{ll}3.49 & 14 \\
3.55 & 12 \\
\text { NS }\end{array}$ & $\begin{array}{l}\text { NS } \\
\text { NS }\end{array}$ \\
\hline B & Asbestos substitute fibers & $\begin{array}{l}\text { Research } \\
\text { Knowledge transfer } \\
\text { P-value Wilcoxon test }\end{array}$ & $\begin{array}{l}3.32 \\
3.37 \\
\text { NS }\end{array}$ & $\begin{array}{l}19 \\
21\end{array}$ & \begin{tabular}{ll}
3.59 & 12 \\
3.58 & 12 \\
\multicolumn{2}{c}{ NS }
\end{tabular} & $\begin{array}{cc}3.50 & 13 \\
3.51 & 13 \\
\text { NS }\end{array}$ & $\begin{array}{l}\text { NS } \\
\text { NS }\end{array}$ \\
\hline C & Special populations at risk (elderly, minors, disabled people) & $\begin{array}{l}\text { Research } \\
\text { Knowledge transfer } \\
\text { P-value Wilcoxon test }\end{array}$ & $\begin{array}{l}3.42 \\
3.53 \\
\text { NS }\end{array}$ & $\begin{array}{l}16 \\
11\end{array}$ & \begin{tabular}{ll}
3.46 & 14 \\
3.50 & 14 \\
\multicolumn{2}{|l}{ NS }
\end{tabular} & $\begin{array}{ll}3.45 & 15 \\
3.51 & 13 \\
\text { NS } & \end{array}$ & $\begin{array}{l}\text { NS } \\
\text { NS }\end{array}$ \\
\hline $\mathrm{E}$ & $\begin{array}{l}\text { Biological monitoring: identification of markers for } \\
\text { low-dose exposure }\end{array}$ & $\begin{array}{l}\text { Research } \\
\text { Knowledge transfer } \\
\text { P-value Wilcoxon test }\end{array}$ & $\begin{array}{l}3.68 \\
3.53 \\
\text { NS }\end{array}$ & $\begin{array}{r}3 \\
11\end{array}$ & $\begin{array}{cc}3.58 & 13 \\
3.49 & 15 \\
\text { NS }\end{array}$ & $\begin{array}{l}3.61 \quad 11 \\
3.50 \quad 15 \\
0.045\end{array}$ & $\begin{array}{l}\text { ns } \\
\text { NS }\end{array}$ \\
\hline C & Agriculture & $\begin{array}{l}\text { Research } \\
\text { Knowledge transfer } \\
\text { P-value Wilcoxon test }\end{array}$ & $\begin{array}{l}3.15 \\
3.34 \\
0.03\end{array}$ & $\begin{array}{r}24 \\
22 \\
38\end{array}$ & \begin{tabular}{cc}
3.42 & 16 \\
3.48 & 16 \\
\multicolumn{2}{|l}{ NS }
\end{tabular} & $\begin{array}{l}3.3319 \\
3.4416 \\
0.011\end{array}$ & $\begin{array}{l}\text { NS } \\
\text { NS }\end{array}$ \\
\hline B & Occupational exposure to urban chemical pollutants & $\begin{array}{l}\text { Research } \\
\text { Knowledge transfer } \\
\text { P-value Wilcoxon test }\end{array}$ & $\begin{array}{l}3.68 \\
3.63 \\
\text { NS }\end{array}$ & $\begin{array}{l}3 \\
5\end{array}$ & $\begin{array}{cc}3.19 & 19 \\
3.20 & 18 \\
\text { NS }\end{array}$ & $\begin{array}{cc}3.35 & 18 \\
3.34 & 17 \\
\text { NS } & \end{array}$ & $\begin{array}{l}0.003 \\
0.012\end{array}$ \\
\hline D & $\begin{array}{l}\text { Mechanism of action of occupational stress } \\
\text { and occurrence of disease }\end{array}$ & $\begin{array}{l}\text { Research } \\
\text { Knowledge transfer } \\
\text { P-value Wilcoxon test }\end{array}$ & $\begin{array}{r}3.55 \\
3.42 \\
\text { NS }\end{array}$ & $\begin{array}{l}10 \\
18 \\
S\end{array}$ & \begin{tabular}{ll}
3.26 & 18 \\
3.22 & 17 \\
\multicolumn{2}{|c|}{ NS }
\end{tabular} & $\begin{array}{cc}3.36 & 17 \\
3.29 & 18 \\
\text { NS }\end{array}$ & $\begin{array}{l}\text { NS } \\
\text { NS }\end{array}$ \\
\hline E & Methods of assessing and measuring occupational stress & $\begin{array}{l}\text { Research } \\
\text { Knowledge transfer } \\
\text { P-value Wilcoxon test }\end{array}$ & $\begin{array}{l}3.59 \\
3.41 \\
0.03\end{array}$ & $\begin{array}{r}8 \\
19 \\
33\end{array}$ & $\begin{array}{cc}3.31 & 17 \\
3.20 & 18 \\
0.023\end{array}$ & $\begin{array}{ll}3.41 & 16 \\
3.27 & 19 \\
0.003\end{array}$ & $\begin{array}{l}\text { NS } \\
\text { NS }\end{array}$ \\
\hline A & Occupational asthma and respiratory diseases & $\begin{array}{l}\text { Research } \\
\text { Knowledge transfer } \\
\text { P-value Wilcoxon test }\end{array}$ & $\begin{array}{l}3.30 \\
3.48 \\
0.04\end{array}$ & $\begin{array}{r}21 \\
16 \\
48\end{array}$ & 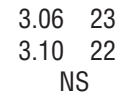 & $\begin{array}{c}3.1423 \\
3.23 \quad 20 \\
\text { NS }\end{array}$ & $\begin{array}{r}\text { NS } \\
0.021\end{array}$ \\
\hline B & Biological agents & $\begin{array}{l}\text { Research } \\
\text { Knowledge transfer } \\
\text { P-value Wilcoxon test }\end{array}$ & $\begin{array}{c}3.03 \\
3.25 \\
0.02\end{array}$ & $\begin{array}{l}25 \\
25 \\
23\end{array}$ & $\begin{array}{c}3.12 \quad 20 \\
3.1920 \\
\text { NS }\end{array}$ & $\begin{array}{c}3.0924 \\
3.2121 \\
0.050\end{array}$ & $\begin{array}{l}\text { NS } \\
\text { NS }\end{array}$ \\
\hline A & Occupational allergies & $\begin{array}{l}\text { Research } \\
\text { Knowledge transfer } \\
\text { P-value Wilcoxon test }\end{array}$ & $\begin{array}{l}3.32 \\
3.38 \\
\text { NS }\end{array}$ & $\begin{array}{l}19 \\
20\end{array}$ & $\begin{array}{cc}3.07 & 21 \\
3.12 & 21 \\
\text { NS }\end{array}$ & $\begin{array}{c}3.1522 \\
3.2121 \\
\text { NS }\end{array}$ & $\begin{array}{r}N S \\
0.004\end{array}$ \\
\hline A & Reproductive and pregnancy disorders & $\begin{array}{l}\text { Research } \\
\text { Knowledge transfer } \\
\text { P-value Wilcoxon test }\end{array}$ & $\begin{array}{r}3.51 \\
3.56 \\
\text { NS }\end{array}$ & $\begin{array}{r}13 \\
9 \\
\end{array}$ & $\begin{array}{cc}2.99 & 24 \\
3.03 & 23 \\
\text { NS }\end{array}$ & $\begin{array}{cc}3.16 & 21 \\
3.21 & 21 \\
\text { NS }\end{array}$ & $\begin{array}{r}0.001 \\
\text { NS }\end{array}$ \\
\hline D & $\begin{array}{l}\text { Individual susceptibility and development of susceptibility } \\
\text { indicators }\end{array}$ & $\begin{array}{l}\text { Research } \\
\text { Knowledge transfer } \\
\text { P-value Wilcoxon test }\end{array}$ & $\begin{array}{l}3.55 \\
3.57 \\
\text { NS }\end{array}$ & $\begin{array}{r}10 \\
8 \\
5\end{array}$ & $\begin{array}{cc}3.07 & 21 \\
2.94 & 26 \\
0.006\end{array}$ & $\begin{array}{c}3.23 \quad 20 \\
3.15 \quad 24 \\
0.014\end{array}$ & $\begin{array}{l}0.004 \\
0.001\end{array}$ \\
\hline C & Air quality and indoor environments & $\begin{array}{l}\text { Research } \\
\text { Knowledge transfer } \\
\text { P-value Wilcoxon test }\end{array}$ & $\begin{array}{l}3.24 \\
3.29 \\
\text { NS }\end{array}$ & $\begin{array}{r}22 \\
24 \\
S\end{array}$ & $\begin{array}{cc}2.94 & 26 \\
2.97 & 25 \\
\text { NS }\end{array}$ & $\begin{array}{cc}3.04 & 25 \\
3.07 & 25 \\
\text { NS }\end{array}$ & $\begin{array}{l}\text { NS } \\
\text { NS }\end{array}$ \\
\hline B & Electromagnetic fields & $\begin{array}{l}\text { Research } \\
\text { Knowledge transfer } \\
\text { P-value Wilcoxon test }\end{array}$ & $\begin{array}{l}2.92 \\
3.03 \\
\text { NS }\end{array}$ & $\begin{array}{l}26 \\
26\end{array}$ & $\begin{array}{cc}2.95 & 25 \\
3.03 & 23 \\
\text { NS }\end{array}$ & $\begin{array}{c}2.9426 \\
3.03 \quad 26 \\
\text { NS }\end{array}$ & $\begin{array}{l}\text { NS } \\
\text { NS }\end{array}$ \\
\hline D & Mechanism of skin absorption of xenobiotics & $\begin{array}{l}\text { Research } \\
\text { Knowledge transfer } \\
\text { P-value Wilcoxon test }\end{array}$ & $\begin{array}{l}2.83 \\
2.85 \\
\text { NS }\end{array}$ & $\begin{array}{l}27 \\
27 \\
\end{array}$ & $\begin{array}{c}2.68 \quad 27 \\
2.73 \quad 27 \\
\text { NS }\end{array}$ & $\begin{array}{c}2.73 \quad 27 \\
2.77 \quad 27 \\
\text { NS }\end{array}$ & $\begin{array}{l}\text { NS } \\
\text { NS }\end{array}$ \\
\hline
\end{tabular}

a Mann-Whitney U Uni-ASL. 
for knowledge transfer than research, in the overall sample and the two subgroups. In contrast, the mean score for "methods of assessing occupational stress" was significantly higher for research than knowledge transfer. The ASL assigned greater importance to research for various topics, such as "new work-related diseases", "work organization and new types of work", "exposure to low doses and multiple exposure", and "individual susceptibility". The universities considered knowledge transfer more important for "agriculture", "occupational asthma", and "biological agents".

Table 4 lists the new priority areas for OSH research and knowledge transfer. The complex topic of "assessment of psychosocial and organizational risks" was the $1^{\text {st }}$ priority for knowledge transfer and ranked $2^{\text {nd }}$ for research. "Risks associated with nanotechnologies" was identified as the top research priority but not highly prioritized for knowledge transfer (11 $1^{\text {th }}$ out of 14$)$.

Another important topic was the "role of occupational health in accident management and prevention", which ranked $3^{\text {rd }}$ for research and $2^{\text {nd }}$ for knowledge transfer. Respondents also expressed interest on the topics "migration and work" ( $4^{\text {th }}$ for research, $3^{\text {rd }}$ for knowledge transfer), and "health promotion" $\left(5^{\text {th }}\right.$ in both rankings). Others areas assigned high priority included: "cost/benefit analysis for prevention", problems related to "subjects previously exposed to carcinogens", and "information flows and recording systems".

"Alcohol, drug addiction and work: legislative issues, prevention strategies and intervention models" and "assessment and management of occupational psychosocial risks: development of intervention and applicability models" were at the bottom of the list of new priority areas for research and knowledge transfer.

\section{Discussion}

It is increasingly important to establish some sort of rating for research areas in view of the limited funding available and the obvious need to use it in the most efficient way possible. In recent years, numerous studies have examined the demand for OSH research, with a view to establishing priorities to respond better to the growing range of requirements to safeguard occupational safety and health. In a previous study (13), we reported a description of the main efforts to identify OSH priorities and made a critical comparative analysis of the approaches taken, the results, and their impact on social, economic, political, and scientific decisions.

ISPESL's long-term approach to the identification of research priorities has reconfirmed the importance of the complex question of "occupational carcinogenesis", which remained high in the rankings of the overall sample and among both ASL and university respondents. "Work accidents" moved up in the rankings; the overall sample and ASL respondents assigned it absolute priority in the latest round.

The importance of these topics in research mainly results from the incidence and prevalence of occupational health diseases. On the other hand, the greater the focus on the need for knowledge transfer, the better the chances to find an explanation in the analysis of existing peer-reviewed papers.

Occupational health includes a wide variety of topics from various fields and the timeliness of the sources is crucial as the half life of most knowledge is limited to 4-5 years. This implies high demands on the availability of relevant knowledge and information (17). Scientific knowledge has always played an important role in occupational health, but the traditional health surveillance methods for determining the time trends of different pathologies are not easy to interpret because over time many confounders and causal factors can interact and change. Therefore, comparative evaluation studies and more systematic evaluation methods are needed. In this respect, the occupational health field of the Cochrane Collaboration, a network of researchers and practitioners in occupational health, made an important contribution

Table 4. New priority areas for research and knowledge transfer identified in the 2007-2008 survey.

\begin{tabular}{|c|c|c|c|c|}
\hline \multirow[t]{2}{*}{ Topics } & \multicolumn{2}{|c|}{$\begin{array}{l}\text { Research } \\
\text { priorities }\end{array}$} & \multicolumn{2}{|c|}{$\begin{array}{l}\text { Knowledge } \\
\text { transfer } \\
\text { priorities }\end{array}$} \\
\hline & $\begin{array}{l}\text { Mean } \\
\text { score }\end{array}$ & Rank & $\begin{array}{l}\text { Mean } \\
\text { score }\end{array}$ & Rank \\
\hline $\begin{array}{l}\text { Risks associated with nanotechnologies } \\
\text { and exposure to nanomaterials }\end{array}$ & 4.92 & 1 & 4.23 & 11 \\
\hline $\begin{array}{l}\text { Assessment of psychosocial and } \\
\text { organizational risks }\end{array}$ & 4.63 & 2 & 4.81 & 1 \\
\hline $\begin{array}{l}\text { Role of occupational health in accident } \\
\text { management and prevention with special } \\
\text { reference to construction }\end{array}$ & 4.57 & 3 & 4.67 & 2 \\
\hline Migration and work & 4.54 & 4 & 4.61 & 3 \\
\hline Health promotion & 4.49 & 5 & 4.49 & 5 \\
\hline Chemicals & 4.40 & 6 & 4.58 & 4 \\
\hline Cost-benefit analysis for prevention & 4.40 & 6 & 4.35 & 9 \\
\hline Subjects previously exposed to carcinogens & 4.37 & 8 & 4.37 & 8 \\
\hline Information flows and recording systems & 4.34 & 9 & 4.41 & 7 \\
\hline Ergonomics & 4.05 & 10 & 4.23 & 11 \\
\hline Noise and vibration & 4.00 & 11 & 4.27 & 10 \\
\hline $\begin{array}{l}\text { Epidemiological studies and diagnostic } \\
\text { protocols for work-related diseases }\end{array}$ & 3.95 & 12 & 4.43 & 6 \\
\hline $\begin{array}{l}\text { Alcohol, drug addiction and work: } \\
\text { legislative issues, prevention strategies } \\
\text { and intervention models }\end{array}$ & 3.83 & 13 & 4.15 & 13 \\
\hline $\begin{array}{l}\text { Assessment and management of occupational } \\
\text { psychosocial risks: development of interven- } \\
\text { tion and applicability models }\end{array}$ & 3.56 & 14 & 4.05 & 14 \\
\hline
\end{tabular}


in collecting and summarizing evaluation studies of occupational health interventions and disseminating the results in the form of a systematic review (18).

The analysis of our findings with respect to occupational carcinogenesis, as well as those of existing peer-reviewed papers, provides insight into published statistics. For example, after cardiovascular diseases, tumors are the second greatest cause of death in Italy, and the numbers are rising continuously 164790 tumor deaths were reported in 2004 (about $30.5 \%$ of all deaths) (19), a steady rise from the 163000 in 2002, 160000 in 2000, and 159000 in 1998 (20). Figures put forward in 1981 by Doll \& Peto (21), and still largely accepted, suggest that about $4 \%$ of all cancer deaths are due to occupational exposures, in a range of $2-8 \%$. In the intervening years, the proportions have been debated and updated and vary with the tumor site and economic sector. For men, the estimates are $13-18 \%$ for lung tumors, $2-10 \%$ for bladder cancers, and $2-8 \%$ for laryngeal tumors (22-24). Using Doll \& Peto's estimates and the figure of 164790 deaths from tumors in Italy in 2004 [even applying the conservative percentage (4\%)], about 6600 of these deaths were presumably due to occupational exposure. The updated figures of the European Union's carcinogen exposure information system (CAREX) for Italy in 2000-2003, covering 21.8 million workers, indicated a total of 4.2 million exposures, which - without going into the question of multiple exposures - is close to $19 \%$ of the whole workforce (25-28).

Ranked $9^{\text {th }}$ out of 27 in the $2000-2001$ priority list, the theme of "work accidents" was identified this time around as the second most important issue urgently needing research and knowledge transfer in our survey. The experts' perception of the risk may have been enhanced by the increasing institutional attention being paid to the problem, the availability of public health statistics, and the increased media coverage.

Even so, according to the Italian Workers' Compensation Authority, in 2007 the number of accidents was much lower than in 2006, in general terms but particularly as regards fatal accidents, which are obviously those with the greatest social and emotional impact. In 2007, there were 912615 reported accidents, about 15500 fewer than in the previous year; this drop of $1.7 \%$ was greater than the $1.3 \%$ reduction already noted in 2006 . However, accidents that occur on the way to, or from, work increased from about 92500 cases in 2006 to 94500 in 2007 (2.2\%). The overall 1.7\% drop in work-related accidents must be seen against the fact that numbers of workers grew 1\% in 2007 [according to the Italian National Institute of Statistics (ISTAT)]; so in relative terms the improvement actually amounts to about $2.7 \%$.

The most interesting point, however, relates to deaths at work. In recent years, such events have shocked the country's civil and social conscience. In 2007, there were 134 fewer deaths at work (1207 deaths) than in 2006 (1341 deaths) (29).

These results should be considered in relation to the knowledge available in the literature. A simple PubMed search reveals the efforts made to transfer knowledge. Using the keywords "carcinogenesis (occup* OR worker*)", PubMed displays 1681 scientific articles, $22 \%$ of which are reviews. There are 23366 articles in the area of work accidents [accident (occup* OR worker*)], $7 \%$ of which are reviews.

For other topics, it was clearly more important to concentrate on the transfer and dissemination of results already obtained than to conduct new research. Examples are issues related to "worker information, education, and participation", "agriculture", and "occupational asthma and respiratory diseases", all of which ranked significantly higher for knowledge transfer than for research. Indeed the existing peer-reviewed papers on these topics are quite limited: a PubMed search for "worker* information education" yielded 2548 scientific papers ( $7 \%$ being reviews); for the agriculture, we obtained 6426 papers, including reviews (6\%).

For other topics, however, research was needed more than knowledge transfer. One such subject was "new work-related diseases", which calls for constant, systematic updating to keep up with emerging risk factors, new forms of work, and work organization. Research also took priority over knowledge transfer for "methods of assessing and measuring occupational stress" and "biological agents".

The utility of dividing the findings in such a way is illustrated by the rankings for the new area related to the risk of exposure to nanomaterials, which topped the list for research priority but ranked only $11^{\text {th }}$ out of 27 for knowledge transfer.

Since the turn of this century, nanotechnology has grown exponentially as confirmed by the number of products on the market and the funds dedicated to research and development. But there is still a vast gap between technological progress and research into health and safety in this field. Studies on the effects of nanotechnologies on health and analysis of the risks of exposure to nanomaterials are still in their infancy; there are no validated methods for risk assessment in the workplace. In view of this imbalance between our scant knowledge of the potential health risks linked to the use of nanomaterials and the exponential spread of this technology, there is a pressing need for research focused on risk analysis for exposed workers (30). A PubMed search for "nanomaterials (occup* OR worker*)" yielded only 297 scientific papers and 34 reviews (11\%).

There is also fast-growing interest in the broad area of psychosocial and organizational risks. The three topics directly linked to these issues - "work organization 
and new types of work", "methods of assessing and measuring occupational stress", and "mechanisms of action of work-related stress and occurrence of disease" - all gained ground in the research priority rankings compared to the earlier findings, but assessment of psychosocial and organizational risks, considered among the emerging priorities, moved up to $1^{\text {st }}$ and $2^{\text {nd }}$ place for knowledge transfer and research, respectively.

A weakness of this study was our use of the Delphi technique to select the panel of experts to be interviewed; since this method is not guaranteed by the sampling theory, priority-setting was done by a selected group of people and may not be representative of other points of view. To make sure the results are reliable and unbiased, the panel must be highly representative of all the bodies involved in the study.

This was a national study that has impact on the political and economic decision-making process of Italy but its implications are far reaching. In light of our findings, efforts are urgently needed to conduct a similar exercise on the international level to identify research and knowledge transfer priorities related to workers' health and safety. This should be done in a standardized and systematic way in order to be able to compare results, avoid the wasteful duplication of resources, and reduce occupational accidents and illness.

The results of this study are important for funding institutions in the OSH research system but also for those stakeholders who might improve the transfer of knowledge process in the field.

\section{Acknowledgement}

We are grateful to JD Baggott for the language revision.

\section{References}

1. de Francisco A. Priority setting in health research. In: Davey S, editor. The 10/90 Report on Health Research 2003-2004. Geneva: Global Forum for Health Research; 2004. p 69-73.

2. Harrington JM. Research priorities in occupational medicine: a survey of United Kingdom medical opinion by the Delphi technique. Occup Environ Med. 1994;51:289-94.

3. Rosenstock L, Olenec C, Wagner GR. The national occupational research agenda: a model of broad stakeholder input into a priority setting. Am J Public Health. 1998;88:353-6.

4. National Institute for Occupational Safety and Health (NIOSH). National Occupational Research Agenda (NORA) [Internet]. Cincinnati (OH): NIOSH; 1996 [cited 4 May 2009]. Available from: http://www.cdc.gov/niosh/nora/; http://www. cdc.gov/niosh/nora/about.html.
5. Van der Beek AJ, Frings-Dresen MHW, van Dijk FJK, Houtman ILD. Priorities in occupational health research: a Delphi study in the Netherlands. Occup Environ Med. 1997;54:504-10.

6. European Agency for Safety and Health at Work. Future occupational safety and health research needs and priorities in the member states of the European Union. Luxembourg: Office for Official Publications of the European Communities; 2000.

7. Iavicoli S, Marinaccio A, Vonesch N, Ursini CL, Grandi C, Palmi S. Research priorities in occupational health in Italy. Occup Environ Med. 2001;58:325-9.

8. Iavicoli S, Signorini S, Petyx M, Ursini CL, Marinaccio A, Capozza G, et al. Delphi study in the identification of research need in occupational medicine in Italy. Med Lav. 2001;92:91-107.

9. Iavicoli S, Grandi C, Signorini S, editors. Research priorities and strategies in occupational health. Italy: Italian National Institute for Occupational Safety and Prevention (ISPESL); 2000.

10. Sadhra S, Beach JR, Aw T-C, Sheikh-Ahmed K. Occupational health research priorities in Malaysia: a Delphi study. Occup Environ Med. 2001;58:426-31.

11. Araki S, Tachi M. National occupational health research priorities, agenda and strategy of Japan: invited report in NORA Symposium 2001, USA. Ind Health. 2003;41:49-54.

12. Fingerhut M, Kortum-Margot E. 2002 Network of World Health Organization (WHO) Collaborating Centres in occupational health, communication and information dissemination. Asian Pac Newsl Occup Health Saf. 2003;9:28-30.

13. Iavicoli S, Rondinone B, Marinaccio A, Fingerhut M. Research priorities in occupational safety and health: a review. Ind Health. 2006;44:169-78.

14. Iavicoli S, Rondinone B, Marinaccio A, Fingerhut M. Identification of research priorities in occupational health. Occup Environ Med. 2005;62:71-2.

15. Graham ID, Logan J, Harrison MB, Straus SE, Tetroe J, Caswell W, et al. Lost in knowledge translation: time for a map? J Contin Educ Health. 2006,26:13-24.

16. Ward VL, House AO, Hamer S. Knowledge brokering: exploring the process of transferring knowledge into action. BMC Health Serv Res. 2009;9:12.

17. van Dijk FJH, Hugenholtz N, A-Tjak M, Schreinemakers J. Knowledge management in occupational health, consequences for structures and functions. Int Congr Ser. 2006;1294:23-6.

18. Verbeek J. The occupational health field in the Cochrane Collaboration. Ind Health 2007;45:8-12.

19. Italian National Institute of Statistics (ISTAT). Preliminary estimation of cause-specific mortality in Italian Regions. Information. 2007;(1).

20. Italian National Institute of Statistics (ISTAT). Causes of death, 2002. Yearbook N. 18, 2007.

21. Doll R, Peto R. The causes of cancer: quantitative estimates of avoidable risks of cancer in the United States today. J Natl Cancer Inst. 1981;66(6):1191-308.

22. Boffetta P, Kogevinas M. Occupational cancer in Europe. Environ Health Perspect. 1999;107 suppl 2:227. 
23. Boffetta P, Kogevinas M. Introduction: epidemiological research and prevention of occupational cancer in Europe. Environ Health Perspect. 1999;107 suppl 2:229-31.

24. Merler E, Vineis P, Alhaique D, Miligi L. Occupational cancer in Italy. Environ Health Perspect. 1999;107 suppl 2:259-71.

25. Mirabelli D. Estimated number of workers exposed to carcinogens in Italy, within the context of the European study CAREX. Epid Prev. 1999;23(4):346-59.

26. Kauppinen T, Toikkanen J, Pedersen D, Young R, Ahrens W, Boffetta $\mathrm{P}$, et al. Occupational exposure to carcinogens in the European Union. Occup Environ Med. 2000;57:10-8.

27. Mirabelli D, Kauppinen T. Occupational exposure to carcinogens in Italy: an update of the CAREX database. Int J Occup Environ Health. 2005;11(1):53-63.

28. Iavicoli S, Persechino B, Petyx M, Rondinone BM. Subjects previously exposed to occupational carcinogens: role and training needs of general practitioners. In: Occupational exposure to carcinogens: which prevention for the previously exposed subjects? Rome: Italian National Institute for Occupational Safety and Prevention (ISPESL); 2006.

29. Italian Workers' Compensation Authority (INAIL). Annual report 2008. Rome: INAIL; 2008.

30. Boccuni F, Rondinone BM, Petyx C, Iavicoli S. Potential occupational exposure to manufactured nanoparticles in Italy. J Cleaner Prod. 2008;16:949-56.

Received for publication: 26 January 2009 